\title{
Reconstructing Historical Theory from the Debris of the Cold War
}

The Antislavery Debate: Capitalism and Abolitionism as a Problem in Historical Interpretation. Edited by Thomas Bender. ${ }^{*}$ Berkeley, CA: University of California Press, 1992. Pp. x, 325. \$14.95.

\section{Morton J. Horwitz ${ }^{\dagger}$}

\section{INTRODUCTION}

Ever since the attack on Beardianism triumphed in the midst of the Cold War, American theoretical discussions of historical method have regularly degenerated into subtle and not-so-subtle Marx-bashing. ' As Charles Beard became the American stand-in for Marx during the 1950's, methodological discussion simultaneously acquired many of the nasty rhetorical forms that were present in the chorus of red-baiting in American culture generally. ${ }^{2}$ Ultimately, the intellectual deformations wrought by Cold War culture led to the disappointing lack of serious discussion of theory or methodology that has long characterized the field of American history. ${ }^{3}$

It comes as quite a relief, therefore, to discover that a sophisticated debate on the relationship between capitalism and slavery can now take place without eliciting in spectators the feeling that it is actually a stand-in for real or imagined positions about the Cold War. The essays in this collection are hopefully an early anticipation of a post-Cold War movement to free historical discussions of capitalism from stale stereotypes and polemics. Yet, at the same time, these essays reveal the extent to which we are still captive to theoretical formulations that emerged under the pressures of the Cold War.

* University Professor of the Humanities and Professor of History, New York University.

t Charles Warren Professor of American Legal History, Harvard Law School. B.A. 1959, City College of New York; Ph.D. 1964, Harvard University; L.L.B. 1967, Harvard Law School.

1. PETER Novick, That NOBLE DREAM: THE "ObJeCtivity QUESTION" AND THE AMERICAN HISTORICAL PROFESSION 96, 462-464, 609-10 (1988).

2. See CEDRIC BELFRAGE, THE AMERICAN INQUiSTION, 1945-1960 (1973); DAVID R. HOLMES, STALKING THE ACADEMIC COMMUNISTS: INTELLECTUAL FREEDOM AND THE FIRING OF ALEX NOVIKOFF (1989); LIONEL S. LEWIS, COLD WAR ON CAMPUS: A STUDY OF THE POLITICS OF ORGANIZATIONAL CONTROL (1988); ELLEN W. SCHRECKER, NO IVORY TOWER (1986).

3. For a notable counterexample, however, see NovICK, supra note 1. 
The Antislavery Debate: Capitalism and Abolitionism as a Problem in Historical Interpretation ${ }^{4}$ captures one of the most important and interesting discussions of historical methodology that has ever taken place in America. As in the great debates among English historians over the enclosure movement, ${ }^{5}$ or the rise and fall of the gentry, ${ }^{6}$ or over cultural and scientific Marxism, ${ }^{7}$ the most important precondition for an illuminating methodological discussion is satisfied, namely that the controversy focus on a particular, concrete problem in historical interpretation.

This debate emerged in 1985 after Thomas L. Haskell challenged, in the pages of the American Historical Review, a certain interpretation of the relationship between capitalism and abolitionist thought in David Brion Davis' monumental study, The Problem of Slavery in the Age of Revolution. ${ }^{9}$ Davis initially seemed shocked that Haskell had chosen to focus on only a small portion of this brilliant and sweeping two-volume comparative study of the history of antislavery thought. Davis' initial wariness, I suspect, was based on some concern that another red-baiting ambush was about to take place, one that he had taken pains to anticipate in his study. But it turns out that Haskell raised some big questions in a respectful and non-demagogic way; that John Ashworth, an English historian, responded thoughtfully to Haskell, ${ }^{10}$ and that Davis himself finally joined the discussion with energy and enthusiasm. ${ }^{11}$ The result is this thought-provoking collection, edited with a fine introduction by Thomas Bender.

4. THE ANTISLAVERY Debate: CAPITALISM AND ABOLITIONISM AS A PROBLEM IN Historical INTERPRETATION (Thomas Bender ed., 1992) [hereinafter cited by page number only].

5. See R. H. TAWNEY, THE AGRARIAN PROBLEM IN THE SIXTEENTH CENTURY (Burt Franklin 1961) (1912); Eric Kerridge, Agrarian Problems in the Sixteenth Century and After, in 6 HISTORICAL PROBLEMs: STUDIES AND DOCUMENTS 119 (1969).

6. See R. H. Tawney, The Rise of the Gentry, 1558-I640, 11 ECON. HIST. REV. I (1941); R. H. Tawney, The Rise of the Gentry: a Postscript, 7 ECON. HIST. REV. 91 (2d ser.) (1954); H. R. Trevor-Roper, The Gentry, 1540-J640, 1 ECON. HIST. REV. SUPPLEMENTS (1953).

7. See Perry Anderson, Socialism and Pseudo Empiricism, New LeFT REV., Jan.-Feb. 1966, at 2-42; E. P. Thompson, The Peculiarities of the English, 1965 SOC. REG. 311-62.

8. Thomas L. Haskell, Capitalism and the Origins of Humanitarian Sensibility, Part l, at pp. 107-35 (originally published at 90 AM. HIST. REv. 339 (1985)); Thomas L. Haskell, Capitalism and the Origins of Humanitarian Sensibility, Part 2, at pp. 136-60 (originally published at 90 AM. HIST. REv. 547 (1985)): see also Thomas L. Haskell, Convention and Hegemonic Interest in the Debate over Antislavery: A Reply to Davis and Ashworth, at pp. $200-59$ (originally published at 92 AM. HIST. REV. 829 (1987)).

9. DAVId BRION DAVIS, THE PROBLEM OF SLAVERY N THE AGE OF REVOLUTION, 1770-1823 (1975).

10. John Ashworth, The Relationship between Capitalism and Humanitarianism, at pp. 180-99 (originally published at 92 AM. HIST. REV. 813 (1987)); John Ashworth, Capitalism, Class, and Antislavery, at pp. 263-89.

11. David Brion Davis, Reflections on Abolitionism and Ideological Hegemony, at pp. 161-79 (originally published at 92 AM. HIST. REV. 797 (1987)); David Brion Davis, The Perils of Doing History by Ahistorical Abstraction: A Reply to Thomas L. Haskell's AHR Forum Reply, pp. 290-309. 


\section{EXPLORING THE LINK BETWEEN IDEOLOGY AND CAPITALISM}

The question posed by Davis about the English abolitionist movement was: "Why did a seemingly liberal movement emerge and continue to win support from major government leaders in the period from 1790 to 1832 , a period characterized by both political reaction and industrial revolution?"12 More generally, Davis asked, what explains the surprising surge of abolitionist thought after 1750, given that for thousands of years slavery had been widely accepted (except by slaves) as part of the natural order of things? What needed explaining was not only the sharp shift in opinion after 1750 , but, more specifically, the emergence of antislavery opinion in a period otherwise characterized by "political reaction and industrial revolution."13

Davis' question regarding the startling movement after 1750 was thus twofold. He queried, first, why those denial mechanisms with which "middleclass Englishmen learned to screen out most of the oppression and suffering in their midst"14 could no longer suffice to suppress recognition of the evils of slavery. Second, and just as significantly, Davis asked how Englishmen could continue to deny the evils of capitalism while pointedly ignoring any analogy between chattel slavery and what was frequently called "wage slavery."

Davis' single answer is that "[t]he emergence of an international antislavery opinion represented a momentous turning point in the evolution of man's moral perception, and thus in man's image of himself. [It] did not spring from transcendent sources: as a historical artifact, it reflected the ideological needs of various groups and classes." 15 For Davis, the emergence of humanitarianism and abolitionism needed to be understood, in a complex and dialectical way, as part of the emergence of capitalism. "The antislavery movement, like [Adam] Smith's political economy, reflected the needs and values of the emerging capitalist order," in Davis' view. ${ }^{16}$ "The paramount question .... is how antislavery reinforced or legitimized such [class] hegemony."17

Haskell challenges Davis' assumption that class interest is the only important link between these screening mechanisms-ideologies-and the system of capitalism. Furthermore, Haskell proposes that capitalism promoted humanitarianism through an expansion of the market, which in turn produced
12. P. 70 .
13. P. 70 .
14. P. 85 .
15. P. 19.
16. P. 71 .
17. Pp. $70-71$. 
a "cognitive style" that emphasized the interdependence of causation and hence the expansion of moral responsibility. ${ }^{18}$

There is much that is interesting, especially for legal historians, in Haskell's formulation. It derives from Sir Henry Maine's idea of a shift from "status" to "contract,"19 which, among other things, can be understood as a contribution to the universalization of moral responsibility. Haskell devotes a good deal of energy to discussing the "growing reliance on mutual promises, or contractual relations," produced by market society. ${ }^{20}$ "Historically speaking," Haskell writes, "capitalism requires conscience and can even be said to be identical with the ascendancy of conscience."21

There are many problems with Haskell's formulation, not the least of which is the excessively abstract nature of his claim. As Ashworth delicately notes, "The market ... had contradictory effects. ... Certainly, [Haskell] was at pains to emphasize the positive effects of the market."22 Haskell also seems to have ignored Davis' specific methodological claim that the problem requiring explanation is not only the relationship of capitalism to humanitarianism, but also the flourishing of antislavery opinion in a period otherwise known for its political reaction and flight from humanitarianism.

But Haskell and Ashworth do raise important questions about how Davis defines capitalism. Is capitalism to be seen as a primarily class-based system with each class having distinct and definable "interests," as Davis sees it? ${ }^{23}$ Should it be thought of primarily in terms of the emergence and expansion of the "market," as Haskell proposes? Or should capitalism be regarded as essentially involving the emergence of wage labor, as Ashworth suggests? Which of these definitions prevails may determine the likelihood that the focus of the debate will stay on Davis' primary interpretive concern-why the abolitionists failed to turn their moral onslaught against the institution of "wage slavery." To Davis, the success of the abolitionists in screening out wage slavery from their moral consciousness is a problem that needs to be explained. For if abolitionism was indeed a subclass of humanitarianism, then one would have expected its critique to be extended. But if the abolitionist failure is instead understood as reinforcing a "hegemonic ideology" of free labor and self-interest, as Ashworth proposes, then one can legitimately see abolitionism in England as a mechanism to displace the emerging moral problems of capitalism. ${ }^{24}$

18. Pp. 111.

19. See HenRy MAINE, ANCIENT Law 295-354 (New York, Charles Scribner \& Co. 1867).

20. P. 144.

21. P. 143.

22. P. 185 .

23. Robert W. Gordon very effectively criticizes the naturalizing of "interest" in Critical Legal Histories, 36 STAN. L. REv. 57, $71-74$ (1984).

24. Another imaginative methodology for avoiding the tendency to give an essentialist definition of class or interest is developed by Robert J. Steinfeld in The Invention of Free Labor: The Employment 


\section{DEFINING IDEOLOGY}

In addition to the very rich discussion of the meaning of class interest and capitalism, Haskell raises questions about how one defines ideology. "By insisting that the reformers were unaware of the hegemonic function served by their ideology," Haskell writes, Davis created a discontinuity "between their intentions and the long-term consequences of their ideas and activities. ... To say that a person is moved by class interest is to say that he intends to further the interests of his class, or it is to say nothing at all."25

Ashworth also considers Haskell wrong on this point, though he faults Davis. Ashworth writes:

Davis has only himself to blame for talking about self-deception and thus opening himself to Haskell's criticism. Davis ought to have focused on 'false consciousness,' the notion that the awareness of historical actors is incomplete, with the result that they misperceive the world around them. ... . But Haskell's objection to the idea of self-deception is quite justified. The way out of this impasse lies, quite simply, in a recognition that society rather than the individual generates false consciousness. ${ }^{26}$

Ashworth's criticism of Davis strikes me as misconceived. Davis' concept of ideology is precisely an attempt to talk about self-deception on a societal scale, analogous to psychoanalytic theories of individual self-deception. ${ }^{27}$ The real question here is whether there is a difference, as Ashworth insists there is, between self-deception and false consciousness. If there is such a difference, which I doubt, it is that deception entails the use of mental screening devices and other forms of intellectual denial, whereas false consciousness proceeds from the disjunction between unmediated thought and "reality."

In its original nineteenth-century usage, ideology also implied a false or distorted picture of reality, in much the same way as the word "myth" once suggested falsehood. But if we surrender the idea that the truth value of thought can be tested for its unmediated correspondence with reality, then the notion of false consciousness must be revised. One can no longer simply say that it is false consciousness for the abolitionists not to have extended their critique to wage slavery. Ashworth's position is thus untenable.

Relation in English and American Law and Culture, 1350-1870 (1991). Steinfeld traces the history of indentured servitude in America to determine whether, at a given time, it was analogized to chattel slavery, at one pole, or to contractual labor, at the other. In the colonial period, Steinfeld shows, indentured servitude was regarded as a form of free labor; but during the nineteenth century it increasingly came to be regarded as closer to chattel slavery. He thus treats indentured servitude as a "mediating" category that illuminates the changing ideological justifications for both slavery and free labor.

25. Pp. 116-17.

26. Id. at 182 .

27. See generally PHILIP RIEFF, FREUD: THE MIND OF THE MORALIST (1961). 
I agree with Ashworth that Haskell's definition of ideology is wrong and entirely unnecessary to his argument, though my analysis differs. The most important question in my view is why Haskell feels compelled to insist on evidence of intentionality, evidence which is ordinarily unavailable to answer the most complex of historical inquiries. Haskell cannot stand by this claim unless he wishes completely to eliminate the indispensable concept of ideology.

Here is where I believe Cold War debates have seriously distorted the canons of historical interpretation. The discrediting of "false consciousness" as an analytical mode calls to mind Cold War polemics about how the concept could be used to justify Stalin, the Gulag, and the policy of "forcing people to be free. ${ }^{28}$ Beginning in the 1950's as part of the attack on Beard, American historians have delighted in discrediting as a "conspiracy theory" any historical inference not documented with concrete proof of intentionality. ${ }^{29}$ Under such rigorous methodological constraints, every discussion of ideology could be condemned as a conspiracy theory, and the only questions that realistically could be answered required highly individualized and biographical modes of proof.

I do agree with Ashworth that we cannot do without the concept of false consciousness. ${ }^{30}$ But until we are able to reformulate the concept to eliminate its original connection to a naive realist epistemology, it cannot serve as a useful way of talking about ideology. Davis' book is one of the most impressive efforts by an American historian to deploy rigorously the idea of false consciousness. Yet, since the denaturalizing of "interest" has encouraged historians to return to "intention" as the only remaining empirical reality, unless we can revive an idea of interest as a social construction, not as an objective manifestation of the desires or needs of a particular class or group, we will not have any anchor for the indispensable concept of ideology. Capitalism, it seems to me, is too broad, too historically varied, and in a postMarxist world, too disputable a concept to serve as such an anchor.

28. See J. L. TALMon, The ORigns of Totalitarian Democracy 38-49, 147 (1985).

29. For discussions of this phenomenon, see works cited supra note 2.

30. P. 182. 